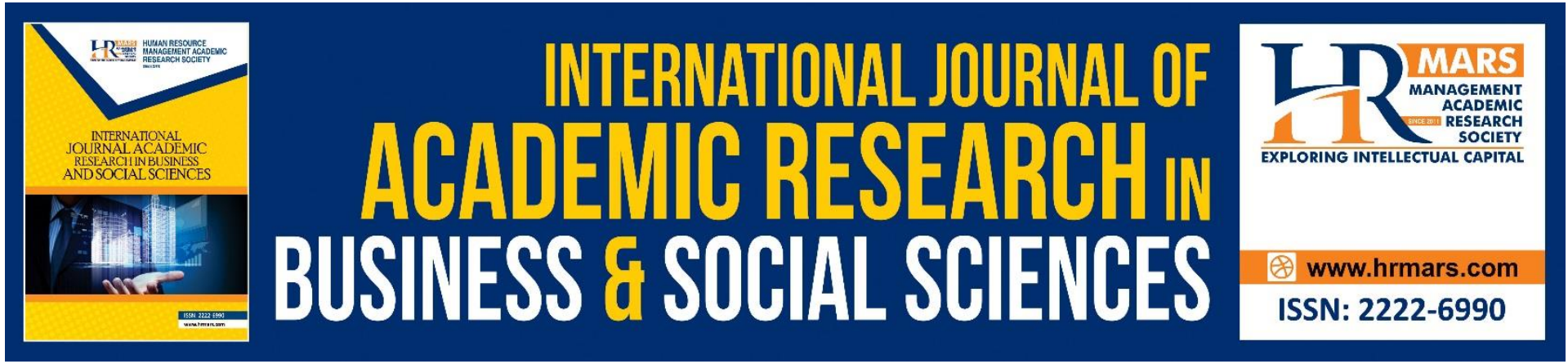

\title{
The Effects of Islamic Recruitment and Selection Towards Person-Job Fit Among Contract Employees of an Islamic Religious Council of Malaysia
}

Muhamad Khalil Omar, Saidatina Rosmaniza binti Saidina Othman, Yusmazida Mohd Yusoff

To Link this Article: http://dx.doi.org/10.6007/IJARBSS/v11-i6/10213

DOI:10.6007/IJARBSS/v11-i6/10213

Received: 13 April 2021, Revised: 17 May 2021, Accepted: 30 May 2021

Published Online: 16 June 2021

In-Text Citation: (Omar et al., 2021)

To Cite this Article: Omar, M. K., Othman, S. R. binti S., \& Yusoff, Y. M. (2021). The Effects of Islamic Recruitment and Selection Towards Person-Job Fit Among Contract Employees of an Islamic Religious Council of Malaysia. International Journal of Academic Research in Business and Social Sciences, 11(6), 828-837.

\section{Copyright: (C) 2021 The Author(s)}

Published by Human Resource Management Academic Research Society (www.hrmars.com)

This article is published under the Creative Commons Attribution (CC BY 4.0) license. Anyone may reproduce, distribute, translate and create derivative works of this article (for both commercial and non-commercial purposes), subject to full attribution to the original publication and authors. The full terms of this license may be seen at: http://creativecommons.org/licences/by/4.0/legalcode

Vol. 11, No. 6, 2021, Pg. 828- 837

Full Terms \& Conditions of access and use can be found at http://hrmars.com/index.php/pages/detail/publication-ethics 


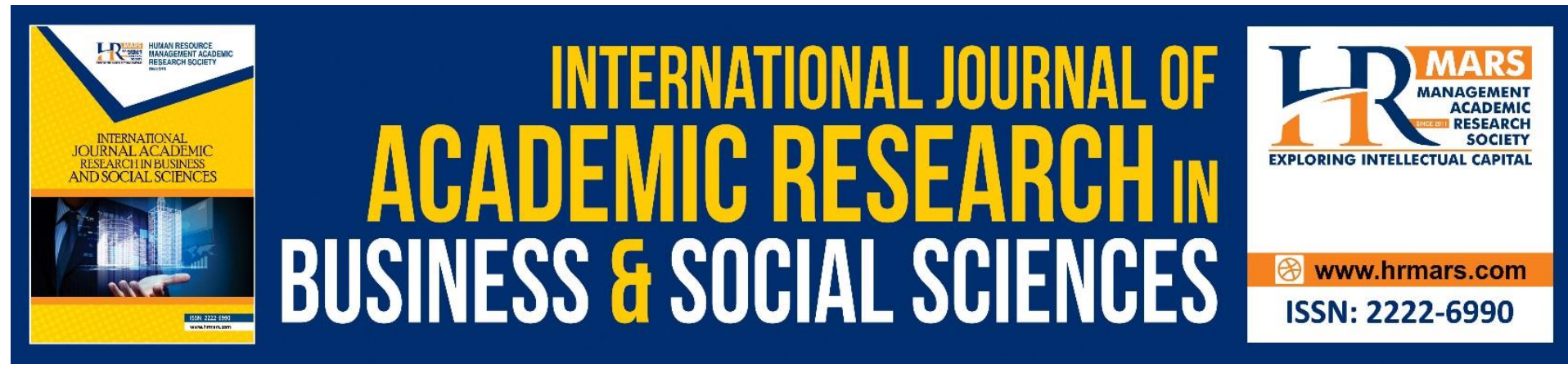

\title{
The Effects of Islamic Recruitment and Selection Towards Person-Job Fit Among Contract Employees of an Islamic Religious Council of Malaysia
}

\author{
Muhamad Khalil Omar ${ }^{1}$, Saidatina Rosmaniza binti Saidina \\ Othman ${ }^{2}$, Yusmazida Mohd Yusoff ${ }^{3}$ \\ ${ }^{1}$ Faculty of Business and Management, Universiti Teknologi MARA Cawangan Selangor, \\ 42300 Bandar Puncak Alam, Selangor, Malaysia, 2,3Faculty of Business and Management, \\ Universiti Teknologi MARA, 40450 Shah Alam Selangor, Malaysia
}

\begin{abstract}
Few articles have focused on the relationship between iHRM and turnover intention. Hence, this study examines the linkage between the Islamic recruitment and selection of employee towards person-job fit among contract employees. Data were gathered from 300 employees at one of Islamic Religious Council in Malaysia using stratified random sampling method and analysed using the SPSS version 21 application. The results show that there is positive relationship between iHRM and turnover intention. Besides, the level of iHRM and turnover intention is in highest score. Finally, the discussion presented.
\end{abstract}

Keywords: Turnover Intention, Islamic Human Resources Management (iHRM), Islamic Staffing, Islamic Human Resources Management (iHRD), Islamic Performance Management, Islamic Compensation.

\section{Introduction}

Human Resource Management (HRM) is an essential element of an organization's success. HRM consists of an organization's "people practices" such as the policies, practices and system that influence employees' behavior, attitudes, and performance. HRM can influences performance of the organization and the employees if it well managed, finely tunes and continuously monitored. Being an Islamic Religious Department, the organization implemented the Islamic value to all the society at all level from individual to institutional such as honesty, responsibility, clean, diligent, just, trustworthy and disciplined for thankful to God. Islam Hadhari, is a national development policy that views based on Islam which was declared by former Prime Minister Dato' Seri Abdullah Badawi that offers a simple approach to embracing the ten principles: faith and piety in God, a just and trustworthy Government, a free and independent people, a vigorous pursuit and mastery of knowledge, balanced and comprehensive economic development, a good quality of live for the people, protection of the rights of minority groups and women, cultural and moral integrity, safe guarding natural resources and the environment, and string defence capabilities (Malaysian Prime Minister 
Office, 2005). Hence, applying Islamic approach in managing the human resource is an advantage for the Islamic organization. But are they really practicing in the Islamic ways for managing the core staffing activities which are recruitment, selection and employment. The HRM is critical to the success of organizations because human capital has certain qualities that make it valuable. Effective management of human resources can form the foundation of high-performance work system. As technology changes, the organization must ensure the organization has the right person to meet the new challenges.

This research has come out with several information or data to the employee about the effect of Islamic recruitment and selection towards person-job fit among the contract employee in one of Islamic Religious Council of Malaysia. Therefore, the intention of this research is to determine whether the Islamic recruitment and selection of employee meets the organization standards towards hires the person that equivalent with the job position.

\section{Literature Review Islamic Recruitment}

According to Junaidah (2009), the recruitment process must be done fairly, and all recruitment decisions must be made wisely, to ensure the hired candidate is best suited for the job. Considering this, Islam requires the person who oversees recruitment to be pious and just. Ahmad (1995) elaborated that a manager should perform religious obligations such as include prayers, fasting, zakat and other pillars of Islam. This is to ensure that the recruitment is fairly conducted, and a just treatment is given to all applicants. A working Muslim who observes his religious obligations would reflect him being a responsible man towards his earthly duties as he us responsible towards God and His command.

In addition, the study also stated that in Islam, one recognized as pious is he who acts in accordance to the commands of god; works in righteousness and prevents himself from evil or harmful acts. Thus, a pious manager is most hoped to be aware of the need for recruitment and other HR practices to be done in the way of God with trust and responsibility. Besides that, Junaidah (2009) cited that the employers are required to inform the truth of facts about the jobs to the applicants. These include the jobs' requirements, the criteria of the job holders, and the compensation to be paid. This information is important to the applicants so that they can evaluate the job suitability with their competency, capability, and interest. The applicants should not be assigned tasks too difficult to handle, neither should they be ordered to do any work beyond their capacity. For example, the Quran states, (2:286): On no soul doth God place a burden greater than he can bear.

\section{Islamic Selection}

From the previous researches, Junaidah (2009) found that religions are generally considered as specific systems of belief, worship, and conduct. According to Metle, (2002), Islam signifies religion as a social order and a way of life which aims at producing unique personalities and a distinct culture for society. The relationship between Islamic practices and human resource functions is significant accordance to guidelines stated in Al-Quran and Hadith. The HRM core businesses that reveal in this article are recruitment, selection, performance appraisal, training and development and compensation towards managing people effectively in Islamic approaches.

The relationship between this article and this study is for the issue of Islamic recruitment and selection. For selection, Ali (2005) cited that that is important Muslim manager to understand the guidelines that prescribe in Al-Quran to avoid bias and 
unprofessional act of the favoritism. There have four principle of selection stated in the research; the first principle is justice which means that to treat or to put a person or a thing at their place or where they belong. Syed Agil (1997), Ali Ibn Abi Talib wrote; "Do not nominate them on account of favoritism or egoism. These two attributes reflect injustice and treachery." Secondly, an employee is selected based on his competency. The Quranic standard of eligibility for a job is the required merit and competence for it. The individual should not be appointed based on friendship ties, wealth, age, race, and political power or alike. Third principle is honesty. Both of applicant and recruiter must be honest. It is important because to ensure the right decision and judgement are made. Honesty also can prevent the recruiter doing any undesired or unlawful actions that contradict the law or legal conduct. Forth principle is Islam forbids assignment of work that will exceed the individual's capacity. This is because the individual may not be able to perform the assigned job due to excessive workload or own limitations. On the other hand, it may harm him as well as the organization where he works.

\section{Person-Job Fit}

The main variables are person-organization fit, person-job fit and employee selection. The relationship between these factors can be described as the recent advancement of the research on P-O fit and P-J fit in employee selection because these two types of fit are considered to be the most influential in the employee selection process. The complementary existing theorist in this field is the concept of P-E fit, P-O fit, and P-J fit. The P-J fit approach has similarly as a dependent variable of researcher's study. Osaka (2004) claims that traditionally, P-J fit is assessed by determining the demand of the job through a job analysis, which identifies job tasks that an incumbent performs, and the requisite skills, knowledge, and abilities to perform the job tasks. Also, this study stated that the high level of P-J fit has several positive outcomes. This statement can be as evidence of the researcher study because it stated that when P-J fit is assessed as the match between what an employee wants and receives from performing job, it is correlated with improved job satisfaction, adjustment and organization-commitment, as well as reduce intention to quit.

\section{Research Framework}

Based on the literature review, the theoretical framework was developed for this study as follows:

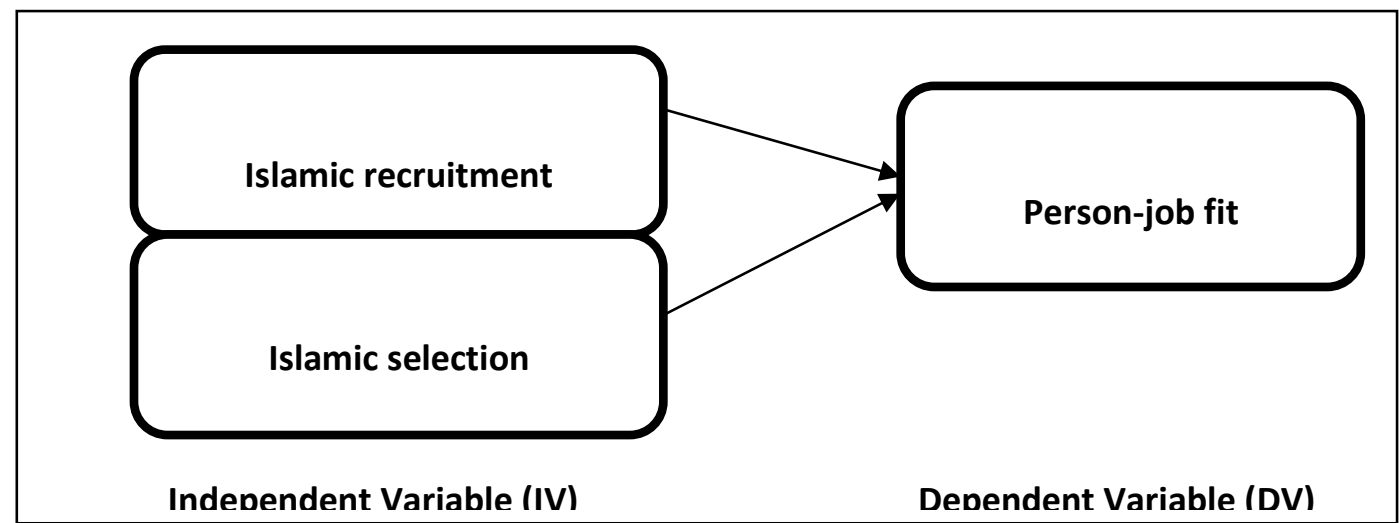

The type of this research is a descriptive research. The total populations of employees are 2589. This research using quota sampling technique. A hundred (100) questionnaires were distributed to the 527 contract employees, who varied in positions at every section of One of 
Malaysia's State Religious Department in order to get their feedback on Islamic approach on Islamic recruitment and selection towards person-job fit. The questionnaires were left with the respondents, to be collected by the researcher between ten minutes to two days. The data collected for this research is by using questionnaires.

\section{Methodology}

\section{Measurements}

Islamic Recruitment is one of the factors in person-job fit. Thus, in order to measure how it's operationalized, the instrumentation was adapted from Junaidah (2009). There were ten items asking how the organizations recruit new employees. All items were measured across 7-point Likert type raging from 1=never, 2=very rarely, 3=rarely, 4=occasionally, 5=frequently, $6=$ very frequently and $7=$ all the times.

Islamic Selection also is one of the factors in person-job fit. Thus, in order to measure how it's operationalized, the instrument was adapted from Junaidah (2009). There were ten items asking how the organizations select new employees. All items were measured across 7point Likert type raging from 1=never, 2=very rarely, 3=rarely, 4=occasionally, 5=frequently, $6=$ very frequently and $7=$ all the times. In term of complimentary P-J fit, three item were including from the scale developed by Lauver and Kristof (2001). These items ask about the employee's fit with the job in terms of skill and personalities. This instrument consists of three items. All items were measured across 5-point Likert type raging from $1=$ strongly disagree, $2=$ disagree, $3=$ =neutral, $4=$ =agree, and $5=$ strongly agree.

\section{Data Collection}

The questionnaire was personally administered. Respondents were volunteered and no incentive for completion was offered. The questionnaires had been distributed to the respondents through face-to-face and give an opportunity for the researcher to introduce the research topic and motivate the despondences to offer their frank and honest answer.

\section{Data Analysis}

Several statistical techniques were utilized using SPSS version 21.0 which are descriptive statistic (percentage), Pearson correlation and Regression analysis.

\section{Results}

\section{Demographic profile}

Most of the respondents were female with 56 (56\%), 81 (81\%) married and 17 (17\%) having bachelor degree, from Islamic Education Division which is 59 (59\%), 71 (71\%) were 26-35 years, 31 (31\%) involve 3-4 years working experience, $53(53 \%)$ respondents have Bachelor Degree, 44 (44\%) having monthly income between RM2000-RM2999 and 55 (55\%) teacher.

\section{Descriptive Analysis}

The result shows that overall mean for Islamic Recruitment is 5.18. The overall highest mean for this variables is item 1 with finding 5.41, it show that majority of respondent agree that the organization reveal the necessary information about the job and the organization to the candidates and the lowest mean for this variable is item 10 with finding 4.83 which minority respondent agree that their organization assesses the candidate competency and interest. 
Table 1: Descriptive Analysis of Islamic Recruitment

\begin{tabular}{|c|c|c|c|c|c|}
\hline No. & Item & Mean & $\begin{array}{l}\text { Std. } \\
\text { Deviation }\end{array}$ & $\begin{array}{l}\text { Skewnes } \\
\text { s }\end{array}$ & $\begin{array}{l}\text { Kurtosi } \\
\mathrm{s}\end{array}$ \\
\hline & COMPOSITE VARIABLE & 5.18 & 0.81 & -.440 & .356 \\
\hline 1 & $\begin{array}{l}\text { To what extent does your organization } \\
\text { reveal the necessary information about } \\
\text { the job and your organization to the } \\
\text { candidates? }\end{array}$ & 5.41 & 1.16 & -.150 & -.555 \\
\hline 2 & $\begin{array}{l}\text { To what extent does your organization } \\
\text { practice Islamic approach in recruitment? }\end{array}$ & 5.38 & 1.17 & -.785 & 1.440 \\
\hline 3 & $\begin{array}{l}\text { My organization informs the candidate } \\
\text { about the job requirement and details. }\end{array}$ & 5.37 & 1.12 & -1.178 & 3.334 \\
\hline 4 & $\begin{array}{l}\text { To what extent does your organization } \\
\text { practice Islamic approach in recruiting the } \\
\text { potential candidates? }\end{array}$ & 5.37 & 1.03 & -.347 & .220 \\
\hline 5 & $\begin{array}{l}\text { To what extent does your organization } \\
\text { give equal opportunity to everyone to } \\
\text { apply for a vacant post in your } \\
\text { organization? }\end{array}$ & 5.29 & 1.10 & -.371 & -.030 \\
\hline 6 & $\begin{array}{l}\text { To what extent does your organization } \\
\text { recruit candidates who are competent } \\
\text { and honest? }\end{array}$ & 5.17 & 1.04 & .041 & .079 \\
\hline 7 & $\begin{array}{l}\text { To what extent does your organization } \\
\text { inform the candidates about the salary } \\
\text { they will receive? }\end{array}$ & 5.11 & 1.14 & -.515 & .282 \\
\hline 8 & $\begin{array}{l}\text { My organization ensures the manager } \\
\text { who is in charged of recruitment is a good } \\
\text { Muslim, pious and just. }\end{array}$ & 4.97 & 1.17 & -.602 & .878 \\
\hline 9 & $\begin{array}{l}\text { To what extent does your organization } \\
\text { recruit candidates responsibly and do it } \\
\text { with full of amanah? }\end{array}$ & 4.87 & 1.13 & -.800 & 1.562 \\
\hline 10 & $\begin{array}{l}\text { My organization assesses the candidate } \\
\text { competency and interest. }\end{array}$ & 4.83 & 0.90 & .260 & .406 \\
\hline
\end{tabular}


Table 2: Descriptive Analysis of Islamic Selection

\begin{tabular}{|l|l|l|l|l|l|}
\hline No. & Item & Mean & $\begin{array}{l}\text { Std. } \\
\text { Deviatio } \\
\mathrm{n}\end{array}$ & $\begin{array}{l}\text { Skewnes } \\
\mathrm{s}\end{array}$ & $\begin{array}{l}\text { Kurtosi } \\
\mathrm{s}\end{array}$ \\
\hline 1 & $\begin{array}{l}\text { COMPOSITE VARIABLE organization believes a good Muslim } \\
\text { will be a good employee. }\end{array}$ & 5.36 & 1.04 & .383 & -1.009 \\
\hline 2 & $\begin{array}{l}\text { My organization feels an Islamic practice } \\
\text { such as prayers and fasting }\end{array}$ & 5.32 & 1.22 & -.097 & -.356 \\
\hline 3 & $\begin{array}{l}\text { My organization considers trustworthy } \\
\text { is an important criteria for an employee } \\
\text { in this organization }\end{array}$ & 5.26 & 1.03 & .133 & -.300 \\
\hline 4 & $\begin{array}{l}\text { The selection decisions in this } \\
\text { organization is done by the committee }\end{array}$ & 5.09 & 1.09 & .198 & -.320 \\
\hline 5 & $\begin{array}{l}\text { My organization when interviewing } \\
\text { Muslim candidates will include } \\
\text { questions pertaining to Islamic } \\
\text { understanding }\end{array}$ & 5.04 & 1.21 & .130 & -.141 \\
\hline 6 & $\begin{array}{l}\text { My organization conducts a test on } \\
\text { candidates' Islamic understanding during } \\
\text { the selection process. }\end{array}$ & 4.98 & 1.19 & .113 & -.531 \\
\hline 7 & $\begin{array}{l}\text { My organization uses Islamic factor in } \\
\text { the selection criteria }\end{array}$ & 4.96 & 1.13 & -.050 & .199 \\
\hline 8 & $\begin{array}{l}\text { My organization informs the candidate } \\
\text { about the job requirement and details. } \\
\text { My organization hires only qualified and } \\
\text { competent candidates }\end{array}$ & 4.89 & 1.13 & .005 & .006 \\
\hline 10 & $\begin{array}{l}\text { My organization uses Islamic } \\
\text { understanding as an important criterion } \\
\text { in selecting candidates. }\end{array}$ & 4.21 & 1.35 & -.392 & .235 \\
\hline & & & .250 & \\
\hline & & & & \\
\hline
\end{tabular}

Table 3: Descriptive Analysis for Person-job Fit

\begin{tabular}{|l|l|l|l|l|l|}
\hline No. & Item & Mean & $\begin{array}{l}\text { Std. } \\
\text { Deviatio } \\
\mathrm{n}\end{array}$ & $\begin{array}{l}\text { Skewnes } \\
\mathrm{s}\end{array}$ & $\begin{array}{l}\text { Kurtosi } \\
\mathrm{s}\end{array}$ \\
\hline & COMPOSITE VARIABLE & 4.25 & .72 & -1.317 & 3.239 \\
\hline 1 & I am the right person for this type of job. & 4.27 & .85 & -1.255 & 1.738 \\
\hline 2 & $\begin{array}{l}\text { My personalities are a good match for } \\
\text { this job }\end{array}$ & 4.25 & .78 & -1.632 & 4.772 \\
\hline 3 & My abilities fit the demand of this job & 4.22 & .81 & -1.353 & 3.262 \\
\hline
\end{tabular}

The result showed that overall mean for Islamic Selection is 5.18. The overall highest mean for this variables is item 1 with finding 5.36, it shows that most of respondent agree that a good Muslim will be a good employee and the lowest mean for this variable is item 10 with 
finding 4.21 which less respondent agree that the organization uses Islamic understanding as an important criteria in selecting candidates. The result also showed that overall mean for person-job fit is 4.25. The overall highest mean for this variables is item 1 with finding 4.27, it shows that most of respondent agree that they are the right person for the type of job and the lowest mean for this variable is item 3 with finding 4.22 which less respondent agree that their ability fit the demand of the job.

\section{Correlation Analysis}

Table 4 shows the correlation between the independent variables and dependent variable. There was a positive correlation and a moderate strong relationship between Islamic Recruitment and Person-job Fit $(r=0.425, p=0.000)$. Thus, the confident level is 99 percent. Meanwhile, there is also a positive correlation and moderate strong relationship between Islamic Selection and Person-job Fit $(r=0.303, p=0.000)$ and the confident level is 99 percent.

Table 4: Correlation Analysis

\begin{tabular}{|c|c|c|c|c|}
\hline & & $\begin{array}{l}\text { Islamic } \\
\text { Recruitment }\end{array}$ & $\begin{array}{l}\text { Islamic } \\
\text { Selection }\end{array}$ & Person-Job Fit \\
\hline Islamic Recruitment & $\begin{array}{l}\text { Pearson Correlation } \\
\text { Sig. (2-tailed) } \\
\mathrm{N}\end{array}$ & $\begin{array}{l}(0.906) \\
100\end{array}$ & & \\
\hline Islamic Selection & $\begin{array}{l}\text { Pearson Correlation } \\
\text { Sig. (2-tailed) } \\
\mathrm{N}\end{array}$ & $\begin{array}{l}.466^{* *} \\
.000 \\
100 \\
\end{array}$ & $\begin{array}{l}(0.930) \\
100 \\
\end{array}$ & \\
\hline Person-Job Fit & $\begin{array}{l}\text { Pearson Correlation } \\
\text { Sig. (2-tailed) } \\
\mathrm{N}\end{array}$ & $\begin{array}{l}.425^{* *} \\
.000 \\
100\end{array}$ & $\begin{array}{l}.303^{* *} \\
.002 \\
100\end{array}$ & $\begin{array}{l}(0.866) \\
100\end{array}$ \\
\hline
\end{tabular}

Note : Reliability is in parentheses (Cronbach alpha).

\section{Regression Analysis}

Table 5 Coefficient test show that unstandardized beta, the highest beta is Islamic Recruitment ( $(=0.0325)$ and significant $(p=0.001)$ it is supported the Hypotheses $1=$ There is a positive relationship between Islamic recruitment with the person-job fit and the $\mathrm{H} 1$ is accepted. The coefficient table is also show that unstandardized beta for Islamic Selection ( $~=0.107$ ) but it is not significant ( $p=0.197)$, thus it is not supported the Hypotheses 2 and the $H_{B}$ is not accepted, thus $H_{0}$ is accepted = There is no relationship between Islamic Selection with the Person-job Fit. For the conclusion, if Islamic approach in recruitment practice is increase, it will also increase the level of Person-job Fit in SSRD. 
Table 5: Regression Analysis

\begin{tabular}{|c|c|c|c|c|c|c|}
\hline \multirow{2}{*}{\multicolumn{2}{|c|}{ Model }} & \multicolumn{2}{|c|}{$\begin{array}{l}\text { Unstandardized } \\
\text { Coefficients }\end{array}$} & \multirow{2}{*}{$\begin{array}{l}\text { Standardized } \\
\text { Coefficients } \\
\text { Beta }\end{array}$} & \multirow[t]{2}{*}{$\mathrm{t}$} & \multirow[t]{2}{*}{ Sig. } \\
\hline & & B & Std. Error & & & \\
\hline \multirow{3}{*}{1} & (Constant) & 2.031 & .467 & & 4.349 & .000 \\
\hline & \begin{tabular}{|l|} 
Islamic \\
Recruitment
\end{tabular} & .325 & .092 & .363 & 3.523 & .001 \\
\hline & Islamic Selection & .107 & .083 & .134 & 1.299 & .197 \\
\hline
\end{tabular}

a. Dependent Variable: Person-job fit

\section{Conclusion}

On the relationship between the independent variables (Islamic recruitment and Islamic selection) and dependent variable (person-job fit) used by the researcher, it can be concluded there are a significant related between each other and moderate strong relationship proven by the findings previously using Pearson's Correlation analysis. The coefficient table show that Islamic recruitment is significant and supported the Hypotheses 1 which is accept the HA = there is a positive relationship between Islamic recruitment with the person-job fit. However, Islamic selection is not significant, thus it is not supported the Hypotheses 2 and the HB is not accepted, thus $\mathrm{HO}$ is accepted $=$ There is no relationship between Islamic selection with the person-job fit. This finding had revealed that the One of Malaysia's State Religious Department has practice Islamic in recruitment and selection towards person-job fit. Between these two independent variables, the Islamic recruitment is the major factor that effect towards the person-job fit rather than Islamic selection. Therefore, when Islamic recruitment practice is increase, it will also increase the level of person-job fit.

Go further; there is also no difference between male and female in term of Islamic recruitment, Islamic selection and person-job fit. Therefore, it is not supported the Hypotheses 3 which is the HC. Thus, $\mathrm{HO}$ is accepted = there is no differences between male and female in term of Islamic recruitment, Islamic selection and person-job fit. Meanwhile, there were differences among different group of marital status and age in term of Islamic selection. There was also difference among different group of monthly income in term of Islamic selection and person-job fit. According to Junaidah (2009), indicate that her study has revealed that the Islamic HRM has been accepted and adopted by companies in Malaysia and it is important that the audience know that the Islamic HRM is tolerant and relevant.

Future studies should include more Islamic organizations and also include a larger sample size to make the findings more accurately. In future, the data can be obtained from different groups of employee such as from recruiter rather than employee itself to get the various perceptions. Hence, the future research also can attempt to discover the effect to the other staffing core business like training and development, compensation, performance, etc.

\section{Acknowledgement}

This research is funded by the Fundamental Research Grant Scheme (600-IRMI/FRGS 5/3 (014/2019) from Universiti Teknologi MARA, Bandar Puncak Alam, Selangor, Malaysia.

\section{Corresponding Author}

Muhamad Khalil Omar, Faculty of Business and Management, Universiti Teknologi MARA Cawangan Selangor, 42300 Bandar Puncak Alam, Selangor, Malaysia.

Email: khalil.omar@uitm.edu.my 


\section{References}

Carolyn Wiley. (1992),"Recruiting Strategies for Changing Times", International Journal of Manpower, vol.13Iss 9 pp. 13-22. October 8, 2014 from http://dx.doi.org/10.1108/01437729210020688

Boon, C., Deanne, N. D. H., Boseli, P., Paauwe, J. (2011), "The relationship between perception of HR practices and employee outcomes: examining the role of person-organisation and person-job fit", Journal of Human Resource Management, Vol. 22, No. 1, pp. 138-162, January 2011 from http://www.informaworld.com

Hashim, J. (2009), "Islamic revival in human resource management practices among selected Islamic organizations in Malaysia", International Journal of Islamic and Middle Eastern Finance and Management, Vol. 2 Iss 3 pp. 251-267, October 8, 2014, from http://dx.doi.org/10.1108/17538390910986362

Hooi, L. W. (2008), "The adoption of Japanese recruitment practices in Malaysia", International Journal of Manpower, Vol.29 Iss 4 pp. 362-378. October 9, 2014 from http://dx.doi.org/10.1108/01437720810884764

Chi, Nai-W., Pan, Su-Y. (2012), "A Multilevel Investigation of Missing Links Between Transformational Leadership and Task Performance: The Mediating Roles of Perceived Person-Job fit and Person-Organization Fit". Journal of Business and Psychology, Vol. 27 Iss 1. pp-43-56, November, 2014, from www.link.springer.com

Sekiguchi, T. (2004)."Person-organization Fit and Person-job Fit in Employee selection : A Review of The Literature" Osaka Keidai Ronshu, Vol.54, No.6, pp.179-196. 